\title{
A gyermek és a kutya kapcsolata fotók alapján
}

\author{
ENDRŐdY-NAgY OrSOLYA \\ Eötvös Loránd Tudományegyetem, Tanító- és Óvóképző Kar
}

\begin{abstract}
Milyen kapcsolatról tanúskodnak a gyermeket és kutyát ábrázoló fotók? Annak érdekében, hogy az emlitett témával kapcsolatos gyermekképet kibonthassuk, arra kértük olvasóinkat, hogy küldjenek fotót a kedvencükröl és gyerekekröl. 15 képet kaptunk, amely kutyát ábrázol. Collier sorozatelemzési módszerét alkalmazva kibontható, a kutya mint a gyermek társa, barátja paradigma. Feltehetjük a jogos kérdést, vajon ki igényli a gondoskodást inkább a gyermek vagy a kutya. A tanulmány bemutatja a képtípus ábrázolásának történeti hagyományát, a kutya mint szimbólum ikonográfiai értelmezését. Az áttekintés során különös figyelmet szentelünk a gyermek-kutya témájú festmények sorának, például Briton Rivière Szimpátia cimü képének. A tanulmány a vizuális antropológiáról is értekezik.
\end{abstract}

Kulcsszavak: vizuális antropológia, gyermekkép, ikonográfia, kutya és gyermek, barátság

Az alábbi cikkben egy kísérlet eredményét láthatjuk. A lapszám készítéséhez beküldött fotók elemzése segíthet a képen szereplők lelkiállapotának, a kutyával asszisztált foglalkozások iránti attitűdjét kirajzolni. Egy lehetséges elemzési módszer Collier (2010) fotóssorozatokra alkalmazható metódusa, az esetleges képtípustörténeti előzmények felvillantásával. A módszer elmélyítheti ismereteinket a kutya-gyermek típusú képekkel kapcsolatosan. Elsőként álljon itt egy rövid áttekintés a vizuális antropológiával és a szűkebb értelemben vett képelemzés módszertanával kapcsolatosan, majd a kutyák ábrázolásával kapcsolatos képzőművészeti háttér rövid áttekintése után a beküldött képek sorozatelemzése következik.

\section{A vizuális antropológia módszertanáról ${ }^{1}$}

A vizuális antropológia felteszi azt a fontos kérdést, hogy mi az, ami hasznos, ami használható a vizuális kutatásban, melyek az előrevivő elemek, tények egy képpel, vagy képsorozattal kapcsolatban (Collier, 2010). A vizuális antro-

\footnotetext{
1 A módszertanról részletesebben l. a Gyermeknevelés 2017/ 1. számát, illetve a szerző 2015-ben publikált monográfiáját. A felhasznált irodalomban 2017a-val szerepel.
}

pológia a rögzítésre, a jelen és a múlt útjainak leírására fókuszál. Vizsgálata mindig az adott közösségekből indul ki, ugyancsak elmondható, hogy a gyakorlatra figyel. Tulajdonképpen a vizuális antropológia különféle lencséken keresztül vizsgálja a személyes és kulturális identitást. Minden esetben a vizuális rögzítés karakterét próbálja megfogni és mintázatok után kutatva értelmezni a látottakat (Collier, 2010). A vizuális antropológia vallja, hogy a fotók és az egyéb vizuálisan rögzített képek, információs tárolók; bár azt az illúziót kelthetik, hogy csupán a szépséget vagy más elvont fogalmat kívánnak bemutatni, mindig hordoznak mélyebb jelentést. Ha sikerül feltárni ezt a jelentést, mélyebb ismeretre tehetünk szert a képen szereplők hozzáállásával kapcsolatban. A vizuális antropológia feladata nem merülhet ki a fotók elemzésében, mint azt sokan gondolják, mindig szem előtt kell tartanunk, hogy a pedagógia számára értelmezhető dokumentumként hasznosítani tudjuk az adott képet, vagy sorozatot. Ebben segíthet a vizuális antropológia (Mietzner és Pilarczyk, 2005).

Sztompka szerint a kódolt, összetett, többrétegü jelentések mélyére, a rejtett dimenziókba kell hatolnunk, ami sokszor az eltérő kultúrájú közösségek percepcióinak különbözőségét eredményezi (Sztompka, 2009), erre jelenthet példát a vallási, világnézeti, szubkulturális felfogások sokasága, vagy a térbeli, 
időbeli távolság. Így mindig szem előtt kell tartanunk, hogy a mi értelmezésünk csupán egy a lehetséges olvasatok közül.

Bán András a vizuális antropológiát a kulturális antropológia részterületének tartja (Bán, 2008; Endrődy-Nagy, 2015). A jelen világában a globális vizuális kultúra vizsgálatának, értelmezésének igénye szükségessé vált. Véleménye szerint a képrobbanás és vizuális robbanás jelenlegi állapotának indoka az is, hogy a globalizált világban a kép sokkal jobban érthető közvetítőnek számít, mint korábban. A kép szerepe tehát rohamosan növekszik. (Nyíri, 2007; Bán, 2008; EndrödyNagy, 2015) ${ }^{2}$. A technikai vívmányok ezt a folyamatot felgyorsítják, ugyanakkor a társadalmi közmegegyezésen, tudatosságon alapuló képolvasás nagyon kezdetleges. A képolvasás analfabétáinak száma napról napra növekszik, ugyanakkor az emberi kapcsolatokban és az információközlésben rohamosan nő a kép szerepe (Bán, 2008. 207-210. o.). Mindennek a képolvasási tudásnak a koncepcionális kialakítása kutatói feladat. Meg kell tanulnunk újra a képeket olvasni és értelmezni, annak érdekében, hogy a képi fordulat után a jelen világban biztonsággal eligazodjunk. Fontos kijelenteni, hogy az antropológiai nézőpont nem a technikából vagy a képalkotás gyakorlatából indul ki, hanem új típusú diszkussziót igényel (Belting, 2003. 10. o.). Ezzel Belting azt fejezi ki, hogy nem szabad a technikai részletekben elveszni, ennél fontosabb lehet másfajta nézőpontok bevonása is a képelemzés folyamatába.

Egy lehetséges viszonylag egyszerübben értelmezhető módszerként nézzük a vizuális antropológiai képelemzési módszert Collier olvasatában (Collier, 2010. 39. o.; EndrödyNagy, 2015, 2017b):

1. „Hagyatkozzunk érzéseinkre, nézzük az egész adathalmazt egységként és rögzítsük az érzéseinket. Hagyjuk, hogy minden benyomás felszínre

\footnotetext{
${ }^{2}$ A képek szerepének és a képi gondolkodás elsődlegességének kutatásával foglalkozik a BME-MTA Képi Tanulás Mühelye, melynek jelen kutatás szerzője is tagja (Nyíri, 2016; Veszelszki, 2017; Endrődy-Nagy, 2017).
}

jöjjön, minden kérdést rögzítsünk, ami motoszkál bennünk, lehet, hogy a későbbi analízisnél fontos irányba terel."

2. „Készítsünk leltárt minden képről, a cél függvényében, hogy mit szeretnénk feltárni, készítsünk kategóriarendszert."

3. „Strukturáljuk az elemzést, mérjünk távolságot, számoljunk, hasonlítsunk. $\mathrm{Az}$ evidens kérdéseket is vizsgáljuk meg. Alapos leírásokat készítsünk, és ha szükséges legyenek grafikonok, statisztikai számítógépes elemzések."

4. „Keressük meg a szignifikáns elemeket, úgy, hogy ismét az egészet nézzük, az összes elemet együtt. Ez alapján írjuk le a konklúziót."

Ez a módszer elsősorban sorozatelemzésekre alkalmas, azért, mert több hasonló témájú képet tudunk a segítségével összehasonlítani. Az intuíciónak teret engedve juttathatja érvényre benyomásainkat, amelyeket már a sorozatra először rápillantva észlelünk. Mindezek miatt a módszer alkalmas lehet a tanítási folyamatba beágyazásra is, a diákok és pedagógusok saját észleléseiket egyeztethetik a képekről való diszkusszió során.

\section{A képanyag}

A lapszám összeállításakor a szerkesztőség felhívást tett közzé, melyben jelezte, hogy vár a kutya és gyermek kapcsolatra vonatkozó fényképeket ${ }^{3}$. Ezek közül az alábbiakban a kutyával kapcsolatos egyéni interakciókat kívánjuk a fent említett Collier-féle sorozatelemzésnek alávetni a galériába való feltöltés sorrendjében. A képek megjelenése két kategóriába szerkesztve a következő: egyéni interakciók, illetve csoportos (osztálytermi) ábrázolások. A képek elemzésére vállalkozó kutató által megismert adatok megegyezek azzal az információval, melyet a képre állított kurzorral elő lehet hívni. İgy összességében 15 egyéni interakciót ábrázoló fotót és 35 cso-

\footnotetext{
3 A felhívás pontos szövege így szólt: „Kérjük tehát vállalkozó kedvű Olvasóinkat, juttassák el digitális képeiket tif vagy jpg formátumban 300 dpi felbontással a szerkesztőséghez, melyek a gyermekek állatokkal való kapcsolatát mutatják be."
} 
A gyermek és a kutya kapcsolata fotók alapján

portos (osztálytermi) fényképet két sorozatba rendezve lehet elemezni. Jelen tanulmány keretei közt az egyéni képek elemzésére vállalkozunk. A kedves olvasó a galériára közvetlenül a két csoport elnevezésére kattintva találhatja. Ahhoz, hogy egy kis áttekintést kapjunk a kutyához kapcsolódó szimbolikus jelentésekről, nézzük mi mindennel ruházták fel az elmúlt évszázadokban az ember hűséges barátját a képzőművészek.

A kutya mint szimbólum jelentése és ábrázolásának jellemzői a képzőművészetben

Az ember hűséges társa, kísérője, általában pozitív jelentés kapcsolható hozzá, hit és ragaszkodás, lényeges jelentései: hűség, őrző, híradó; a bozontos kutya jelentené a negatívumot (1. 1. ábra) (Körber et al., 1994. 199. o.; Endrödy-Nagy, 2015; Carr-Gromm, 2015).

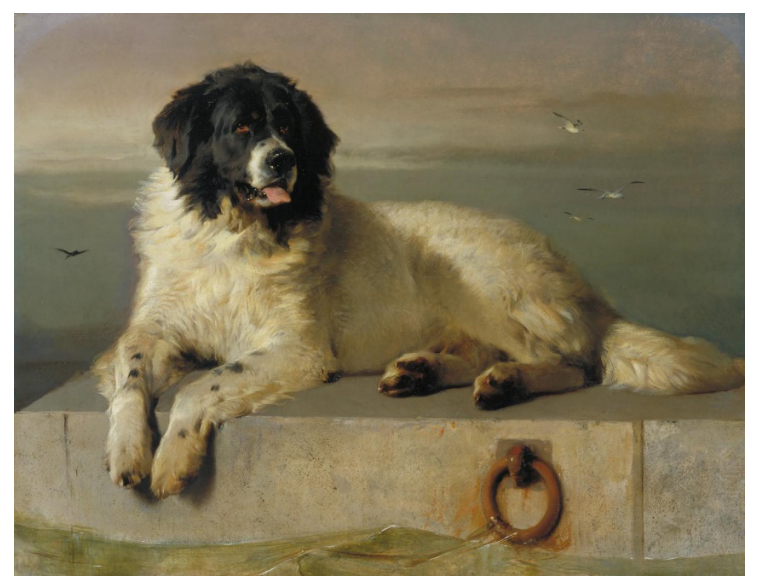

1. ábra: Sir Edwin Landseer: Az emberi társadalom tiszteletbeli tagja, 1831, Tate Gallery, London, olaj, $1118 \times 1435 \mathrm{~mm}$

A Jelképtár, ugyanakkor, egyértelmű halálszimbólumként, lélekvezető állatként, lélekkísérőként jellemzi a kutyát. (Hoppál és mtsai, 1990. 131. o.). Carr-Gromm kiemeli, hogy a középkori síremlékeken feltűnik a gazda lábánál mint gyászolója. Lássuk példaként a 2 . ábrán Maître miniatúráján a beteg gyermeket kísérő, a csüggesztett fejű kutyát előtérbe helyező alkotást (Endrödy-Nagy, 2015.).

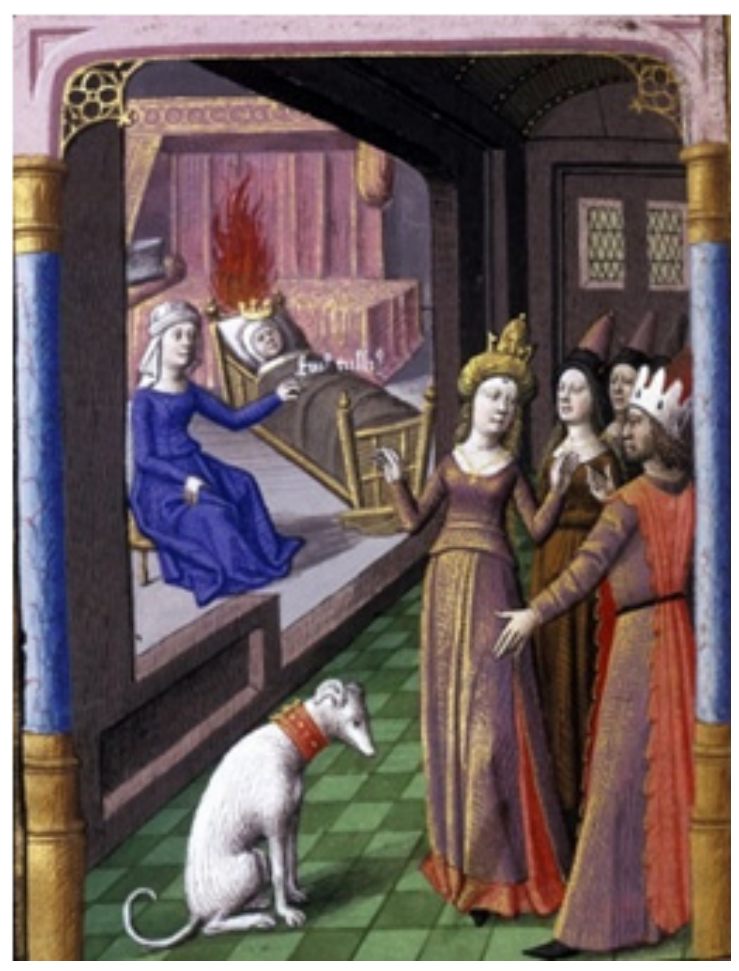

2. ábra: François Maître 1473-1480 - a Les Fais de le Dis des Romains et de autres gens című munkájából British Library, Harley 4375, miniatúra, 475 x 350 mm

Az alvilág kapuját a három(kutya)fejü Kerberosz őrzi (Carr-Gromm, 2015). Erre utal a legújabb idők egyik nagy kedvenc irodalmi alkotásában, a Harry Potterben feltűnő háromfejü kutya is (Belovári, 2016). A kutyák az ókori vadászjeleneteken, később az arisztokrácia vadászportréin is megjelennek. (CarrGromm, 2015, 273.) Ha belegondolunk, a vadászat is a halálhoz kapcsolható, így nem meglepő, ha a kutya ábrázolása valóban sokszor szervesen összekapcsolódik a halál, halandóság gondolatával.

A jelentések közül még ki szokták emelni, hogy Szent Rókust gyakran ábrázolják kutyákkal a Domonkos-rend nevére utalásként a latin domini canis szójátékkal, azaz az 'Úr, vagy Isten kutyáival'. A Rókus-legenda ezt annyival egészíti, ki, hogy mikor a pestist Rókus elkapta, egy kutya gyógyította meg, és ezután vált a pestisesek és betegek védőszentjévé (Carr-Gromm, 2015).

A 19. századtól a gyermeki ártatlanság, bájosság, kedvesség ábrázolásának megjelenítésére nem csak a porcelánszínű bőr, fehér ruha, de sokszor a kísérőként megjelenő 
kutya is a báj fokozására szolgált. Álljon itt ennek példájaként Briton Rivière Szimpátia című 1877 körül készült alkotása. A 3. ábrán láthatjuk, hogy a művész a kutya kis gazdája vonásait, mimikáját hasonlóra festette. A kutya és a kislány tekintete ugyanúgy álmodozást, elvágyódást fejez ki. A kutya társa, talán magányának oldója is egyúttal, merül fel bennünk a kérdés. Vajon miért ül egy bezárt ajtó előtt a lépcsőn a díszes, szép ruhába öltöztetett, lakkcipős kislány?

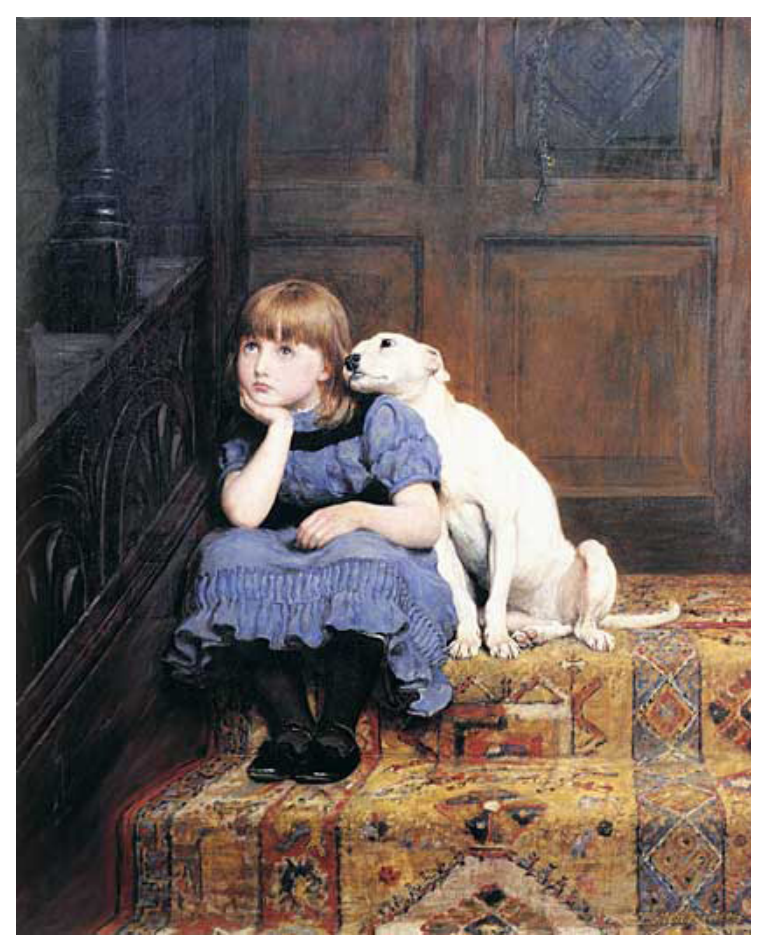

3. ábra: Briton Rivière: Szimpátia, 1877. Royal Holloway, University of London, olaj, 121.8 x 101.5 cm

Amíg gondolkozunk a kép további jelentésein áttérhetünk az aktuális Gyermeknevelés lapszám fotóira, vizsgáljuk meg az ún. egyéni fényképeket, melyen egy-egy gyermek és egy kutya kapcsolatát láthatjuk rögzítve.

\section{Az egyéni sorozat}

Nézzük a Collier-féle elemzés lépéseit az egyéni képeken, fontos, hogy minden érzést, bennünk motoszkáló gondolatsort lejegyezzünk és ezeket a gondolatokat vezessük végig az elemzésen, attól függően, hogy mit szeretnénk megvizsgálni.
1. Az egyéni sorozat képeit először átlapozva a következő érzéseket rögzíthetjük:

- A kutya és a gazdája, vagy a vele foglalatoskodó gyermek barátságos egymással, néhány képen tartanak egymástól, néhány képen bensőséges kapcsolatra utal.

- A gyermek és a kutya figyel egymásra, tekintetük összetalálkozik, vagy egyéb módon kapcsolódnak össze, például összebújva egy irányba tekintenek, egységként kezelhetőek?

- Első ránézésre úgy tűnik, de vajon tényleg összhangban vannak-e egymással a kutya és a gyermek vagy gyermekek?

- Úgy tünik, hogy általában egy gyermek és egy kutya kapcsolatának elkapottnak tűnő (spontán) pillanatát rögzíti a kép.

- Felmerülhet még a szelídség kérdése is, ezt talán érdemes megvizsgálni az elemzés következő lépésében, hány fotón látszik szelídnek a kutya és a vele játszó gyermek? Ha nem szelíd valamelyik résztvevő, az miért lehet?

- Gondoskodás: A képeket átböngészve többet is találhatunk melyen a gyermek a kutyáról gondoskodik, például fésülgeti. Vajon ki gondoskodik kiről? Ki kinek és milyen típusú szükségletéről gondoskodik?

- A játékosság ugyancsak feltűnő, játékosság, de ugyanakkor nyugalom, beletörődés és béke lengi be a fotókat. Átszellemült nyugalom, az a fajta, amelyet akkor érzünk mikor belefeledkezünk egy boldog pillanatba.

2. Mivel elsősorban a képsorozat gyermekképére, annak kibontására vagyunk kíváncsiak a fent leírt első benyomások alapján többek közt a következő kategóriákat kereshetjük a képeken:
a szereplők leírása
b spontaneitás kérdése
c mimika és gesztus
d térköz
e a tevékenységek megnevezése
f gondoskodás kérdése
g játékosság kérdése 
A gyermek és a kutya kapcsolata fotók alapján

h lelkiállapot, boldogság, szelídség megjelenése a fotókon

Ezek után még készítsük el a leltárt!

2a. Szereplők: egy gyermek és egy kutya kapcsolatát 14 fotó ábrázolja, két gyermek és egy kutya interakcióját 1 képen láthatjuk. (1 képen látszik még két gyermek lába, de az arcuk és mimikájuk nem lászik ezért 1 szereplősnek tekinthető a kép.) 2 képen kisbabát látunk, 3 képen óvodáskorú gyermeket és 9 fotón egyértelműen kisiskolást, 1 kép, ahol a két kislány van bizonytalan, de valószínüleg legalább az egyik kisiskolás.

2b. Spontaneitás: Mindegyik kép elkapott pillanatban készülhetett, a spontaneitás megállapítása mindig kérdéses, de az alkotók jelzése alátámaszthatja a spontaneitás kérdéskörét, így megkockáztathatjuk azt a kijelentést, hogy spontán szituációkat ábrázolnak a képek.

2c. Mimika és gesztus: mosolygó gyermek, huncut tekintettel vagy bujkáló mosollyal: 8 kép, 3 kép van, ahol a gyermek nagyon koncentrál a tevékenységre, 1 képen mindketten alszanak, a kisbaba az egyik képen annyira megörül a kutya látványának, hogy szinte hallani, ahogy elkurjantja magát örömében. Az alvó kép kivételével az összesen az öröm csillan a gyermekek szemében, öröm és felszabadultság. 8 esetben nézik egymást, találkozik a tekintetük,3 esetben egy irányba figyelnek, 3 esetben a kutya figyeli a gyermek tevékenységét, 1 esetben mélyen alszanak.

2d. Térköz: 8 olyan képet látunk, melyen a gyermek hozzáér a kutyához, ebből 2 esetben megöleli, átkarolja, 4 esetben simogatja, 1 esetben a 2 kislányos képen, az egyik kislány ráhajol, arcuk összeér, és 2 olyan képet látunk, ahol a kisfiú fésüli a kutya bundáját. A többi 7 fotón is egy méteren belül egymás közvetlen közelében látjuk a gyermeket és a kutyát.

2e. Tevékenységek: alvó, fekvő kutya és gyermek: $3 \mathrm{db}$, fekvő kutya, guggoló, ülő gyermek: $5 \mathrm{db}$, álló kutya, álló vagy futó gyermek, álló kutya: $3 \mathrm{db}$, fekvő gyermek, ülő kutya: $2 \mathrm{db}$, álló gyermek ülő kutya: $1 \mathrm{db}$, guggoló gyermek, ülő kutya: 1 db 2f. Gondoskodás: 7 olyan képet látunk, ahol a kutya egyértelműen őrzi a gyermeket, azaz álmát vigyázza, vagy figyel rá, amint a kiságyban nézelődik, 1 képen a kisfiú mellet fut a kutya, 1 képen buzdítja a kutyát fürdésre, vagy legalább a megmártózásra, 7 olyan képet látunk ahol a gyermek simogatja, ezen belül a két Közös percek című Serfőző Mónika által készített képen a gyermek fésülni készül, majd megfésüli a kutya bundáját, és egyetlen kép van, ahol a gyermek a kutya figyelmét kéri, itt ki is gondoskodik kiről?

2g. Játékosság: A figyelj csak címü kép kivételével konkrét játékra buzdítás nem jelenik meg.

2h. Lelkiállapot: 10 képen nyugodt, ellazult állapotban, bensőséges viszonyban látjuk a szereplőket, 1 képen ebből egyértelmüen alszik mindkét fél, a 2 kép melyet Simon Tibor készített a kisbabáról a gyermek és a kutya kölcsönös érdeklődését fejezi ki, a gyermek jó értelemben izgatott, 3 képen pedig a gyermek magatartásával (futás), vagy kezével buzdítja tevékenységre a kutyát.

3. Strukturáljunk és hasonlítsuk össze a rendelkezésre álló adatokat!

A legtöbb képen 1 gyermek és 1 kutya interakcióját látjuk, a gyerekek nagy része iskoláskorú, de egyik sem éri el a kamaszkort. Minden kép spontán reakciókat tükröz nagy valószínűséggel. Több mosolygó gyermeket látunk, mint akiken nem látható az öröm, vagy mosoly kifejezése. Több mint a képek felén, a gyermek és a kutya tekintete találkozik. A gyermek és kutya közti térköz 1 méteren belüli, a képek többségén közvetlen érintkezés történik. Összesen 3 esetben nincs a gyermek és a kutya feje egy magasságban. Teljesen kiegyensúlyozott a gondoskodás a két szereplő közt, ugyanannyi képen gondoskodik a gyermek a kutyáról, mint fordítva, egy esetben a gondoskodás nem megállapítható, hogy kinek van nagyobb szüksége rá.

4. Keressük meg a szignifikáns elemeket és írjuk le a konklúziót! 
Összefoglalva megállapíthatjuk, hogy a szignifikáns elemek a gyermekek életkorán túl, az öröm kifejezései, elkapott, önfeledt, boldog pillanatokat rögzítenek. A gyermekek belefeledkeznek a pillanatba minden esetben, vidáman, felszabadultan, ugyanakkor több esetben a munka jellegű tevékenység és a kompetenciaélmény megélését jelenti számukra a kapcsolat. Az alkotók szeretete, a kamera túloldalán, a gyermek boldogsága az én boldogságom érzés megélése, az empátia megjelenése valamennyi kép sajátja. A képek tanúsága szerint a kutya nem csak barát, de ugyanannyira gondoskodó fél is lehet, mint amennyire a kisgyermek gondoskodhat a kutyáról. A gyermekkép egy szerethető, kompetens, gondoskodó, örömteli, felszabadult gyermek narratíváját rajzolja ki számunkra a befogadók számára, nem utolsósorban kiemelve azt, hogy ennek a felszabadult lelkiállapotnak az elérésében a kutya a legfóbb segítő, a kamera túloldalán álló alkotó, pedig fontosnak tartja, hogy ezt a pillanatot megörökítse, szívébe zárja.

Mindezek után kutatói javaslat lehet a csoportos képek egy-egy sorozatának elemzése hasonló módon, annak ellenőrzésére, hogy a tanulmányokban rögzített gyermeki érzéseket mennyire tükrözi a képsorozat.

\section{Összegzés}

Az egyénekről készített alkotásokból kibontható egyéni üzenetek, ún. rejtjelek minden esetben egy-egy csoport jellemzőjét mutatják, azét a csoportét vagy azon csoportok jellemzőinek metszetét, amelybe vagy amelyekbe valamilyen szempontból az egyén tartozik (Kaptány és Kapitány, 1995). Tekintsünk vissza még egyszer Briton Rivière Szimpátia című képére! Vajon mire vágyik a kislány, miért vágyakozó a tekintete. Szomorú és vágyódó, elgondolkozó arcára a bezárt ajtó jelenthet magyarázatot? Valami olyasmi történik vagy történt az ajtó mögött, amiből ő ki van zárva? Egyedül van, de társa a kutya együttérző módon hajol vállára. A kép megfejtése egy következő tanulmány témája lesz, de összegezzük még egyszer mi mindent jelenthet egy kisgyermek életében a kutya az elemzett képsorozat alapján.

Jelen tanulmányban a képzőművészeti és ikonográfiai áttekintés után a Collier-féle sorozatelemzés segítségével arra következtettünk, hogy a gyermeknek nem csak társat, barátot jelenthet a kutya, de egymásról való gondoskodást, odafigyelést is ${ }^{4}$. Ezt a gondoskodást élheti meg a vakvezető kutya gazdája is (Mészáros, 2017). A gyermek megélheti a kompetenciaélményt a kutya gondozásával, ugyanakkor a kutya teljes figyelmét is megkapva lelki gondoskodást, szeretetet tapasztal. A képek alkotói ezeket a felszabadult, boldog pillanatokat szívesen örökítik meg, számukra örömet jelent a gyermekek mosolya.

A fotók elemzésével megfogalmazhatunk egy feltevést, mely szerint a képzőművészeti alkotásokban fellelhető szimbolikus lélekkísérő, társ jelentésről a jelentés a jelenben a társ, kísérő, barát, gondoskodó jelentésre tevődött át. Ahhoz, hogy ezt a folyamatot történetileg megragadjuk további elemzésekre lehet szükség.

\section{Felhasznált irodalom}

Bán András (2008): A vizuális antropológia felé. Typotex, Budapest.

Belovári Anita (2016): A fekete kutya szimbolikája a Harry Potter-regénysorozatban, in: Kolosai Nedda és M. Pintér Tibor (szerk.): A gyermekkultúra jelen(töség)e, ELTE TÓK, Budapest URL: http://gyermekkultura.tok.elte.hu/docs/ Gyermekkultura_ebook.pdf

Belting, H. (2003): Kép-antropológia. Kijárat, Budapest.

Carr-Gromm, S. (2015): A kódolt müvészet. Holnap, Budapest

Collier, M. (2010): Approches to analísis in visual antropology. In: van Leeuwen, T., Jewitt, C. (eds) (2010): Handbook of Visual Analysis. Sage, Los Angeles - London - New Delhi Singapore - Washington, 35-61.

\footnotetext{
4 Érdekes megerősítést jelenthet ehhez az állításhoz Mészáros Gabriella Szemi nevű vakvezető golden retrieveréről szóló írása a Gyermeknevelés 2017/2. számában.
} 
A gyermek és a kutya kapcsolata fotók alapján

Endrődy-Nagy Orsolya (2015): A reneszánsz gyermekképe - a gyermekkép reneszánsza 1455-1517 között Európában - ikonográfiai elemzés TEPA-Eötvös Kiadó, Budapest

Endrődy-Nagy Orsolya (2017a, szerk.): A gyermekkortörténeti ikonográfia kiáltványa, Gyermeknevelés, 5. 1. sz.

Endrődy-Nagy Orsolya (2017b): A gyermekkortörténeti ikonográfia kutatási irányai és lehetőségei. Gyermeknevelés, 5. 1. Sz., 110-122.

Hoppál Mihály, Jankovics Marcell, Nagy András és Szemadám György (1990, szerk.): Jelképtár. Helikon, Budapest.

Kaptány Ágnes és Kapitány Gábor (1995): Rejtjelek 2. Kossuth, Budapest.

Körber Ágnes, Marosi Ernő, Szilárdfy Zoltán és Végh János (1994): A keresztény müvészet lexikona. Corvina, Budapest.
Mészáros Gabriella (2017): Az utcától a „katedráig" - Szemivel az élet. Gyermeknevelés, 5. 2. sz., 56-58.

Mietzner, U. és Pilarczyk, U. (2005): Methods of Image Analysis in Research in Educational and Social Sciences. In: Mietzner, U., Myers, K. és Peim, N. (eds): Visual History, Images of Education. Peter Lang AG, European Academic Publishers, Bern. 109-129.

Nyíri Kristóf (2007): Idő és kommunikáció, Világosság, 48. 4. sz., 33-39.

Nyíri Kristóf (2016): Elfelejtett képelméletek, Képi tanulás mühelye füzetek 3., 3-55.

Sztompka, P. (2009): Vizuális szociológia. Gondolat, Budapest.

Veszelszki Ágnes (2017): Visual Learning Lab Képi Tanulás Műhelye, Gyermeknevelés, 5. 1. Sz., 188-190.

\section{About the 'child and dog' theme photos}

What kind of relation can we encode if we analyse a series of photos about children and dogs? To describe the conception of childhood regarding the mentioned topic, we asked our readers to send images about their favourite pet while interact some children. We had got 15 photos about dogs. Using Collier's serial analysis, we can see that dogs and children can make friends, dog could be a companion, and we can't be sure who needs to be taken care of the other. In the paper, we discuss about the roots of the type of depiction, the symbolic meaning of the dog in iconography. We focus on child-related images, such as one of the most popular one from Briton Rivière with the title Sympathy. The paper discusses about visual anthropology itself as well.

Keywords: visual anthropology, conception of childhood, iconography, child and dog, friendship

Endrődy-Nagy Orsolya (2017): A gyermek és a kutya kapcsolata fotók alapján. Gyermeknevelés, 5. 2. sz., 59-65. 